\title{
Postyapısalcılığın Söylemsel Ontolojisinin Eleştirisi: Uluslararası İlişkilerde Söylem Dışı Alan ve Eleştirel Gerçekçilik
}

A Critique of Poststructuralism's Discursive Ontology: Extra-Discursive Realm and Critical Realism in International Relations

\section{Klevis KOLASI}

Dr. Öğr. Üyesi, Ankara Üniversitesi, Uluslararası İlişkiler Bölümü

\section{Bu makaleye atıf için}

Klevis Kolasi, "Postyapısalcılığın Söylemsel Ontolojisinin Eleştirisi: Uluslararası İlişkilerde Söylem Dişı Alan ve Eleştirel Gerçekçilik", Uluslararası İlişkiler, Cilt 17, Say1 65, 2020, s. 83100, DOI: $\underline{10.33458 / \text { uidergisi.660652 }}$

Makaleye Erişim İçin: $\underline{\text { https://dx.doi.org/10.33458/uidergisi.660652 }}$

Makale Gönderim: 14 Kasım 2018

Son Düzeltme: 09 Aralık 2019

İnternet Yayım: 18 Aralık 2019

Basım Tarihi: 01 Mart 2020

\section{Uluslararası İlişkiler Konseyi Derneği | Uluslararası İlişkiler E-Posta: bilgi@uidergisi.com.tr}

Bu makalenin tüm hakları Uluslararası İişkiler Konseyi Derneğìne aittir. Önceden yazılı izin almadan hiçbir iletişim, kopyalama ya da yayın sistemi kullanılarak yeniden yayımlanamaz, çoğaltılamaz, dağıtılamaz, satılamaz veya herhangi bir ssekilde kamunun ücretli/ücretsiz kullanımına sunulamaz. Akademik amaçlı alıntılar bu kuralın dışındadır. Yazıda belirtilen fikirler yalnızca yazarına/yazarlarına aittir. UİK Derneğini, editörleri ve diğer yazarları bağlamaz. 


\title{
Postyapısalcilı̆ın Söylemsel Ontolojisinin Eleştirisi: Uluslararası İlişkilerde Söylem Dışı Alan ve Eleştirel Gerçekçilik
}

\author{
Klevis KOLASİ \\ Dr. Öğr. Üyesi, Ankara Üniversitesi, Siyasal Bilgiler Fakültesi, Uluslararası İlişkiler Bölümü, Ankara \\ E-posta:kolasi@ankara.edu.tr
}

\section{ÖZET}

Uluslararası İlişkiler (Uİ) literatüründe postyapısalcılığın göreceli epistemolojisinin sınırlılıkları genellikle kabul edilirken, söylemsel ontoloji kavrayışının uluslararası ilişkilerdeki temel olguları kavramsallaştırmak açısından içerdiği sorunlar nadiren sorunsallaştırılmaktadır. Bu makalenin amacı, sosyal gerçekliği söylemsel veya dilsel pratiklere indirgeyen postyapısalcılığın gerçekçi karşıtı ontolojik varsayımlarına yönelik eleştirel bir inceleme sunmaktır. Makalenin temel argümanı, söylemsel pratiklerin sosyal gerçekliğin kurucuları olarak, sosyal yapılar ile eşit düzeyde görülemeyecekleri ve söylemlerin ancak farklılaşmış ve katmanlı bir ontoloji içinde kavramsallaştırıldıklarında belirli bir etkinlikte işlerlik kazandıklarıdır. Daha spesifik olarak, makale sosyal gerçekliği sadece yorumcu şemalar aracılı̆̆ıla bilebileceğimizi ifade eden epistemolojik göreceliğin, dünyayı söylemsel pratiklerle eşit gören göreceli bir ontoloji kavrayışına götürmek zorunda olmadığını göstermeye çalışmaktadır. Makale bu doğrultuda eleştirel gerçekçiliğin sunduğu meta-teorik çerçeveye dayanmaktadır. Bu amaçla makale, postyapısalcılıktaki teori ile sosyal gerçeklik arasındaki ilişkiyi yeniden ele almaktadır.

Anahtar Kelimeler: Postyapısalcılık, Söylemsel Ontoloji, Söylemsel Pratikler, Eleştirel Gerçekçilik, Katmanlı Ontoloji

\section{A Critique of Poststructuralism's Discursive Ontology: Extra-Discursive Realm and Critical Realism in International Relations}

\begin{abstract}
While the limits of poststructuralism's relativist epistemology are usually acknowledged in IR literature, the problems that its discursive ontology posits for the conceptualization of international phenomena are seldom problematized. This article aims to provide a critical assessment of the anti-realist ontological assumptions of poststructuralism about reducing social reality into discursive or linguistic practices, which has recently gained widespread acceptance in postpositivist circles. The article suggests that discursive practices instead of being equated with social structures, and seen as constitutive of social reality, can be properly understood only if conceptualized within a differentiated and stratified ontology, allowing us to probe why specific discourses emerge in a certain way and have more influence than others. Based on the meta-theoretical framework of critical realism, this article tries to show that epistemological relativism which claims knowledge of social reality only indirectly through interpretive schemas does not necessarily lead to a conception of relative ontology that equates social reality with discursive practices. In this respect, the article focuses on and rethinks the relationship between theory and social reality in poststructuralism.
\end{abstract}

Keywords: Poststructuralism, Discursive Ontology, Discursive Practices, Critical Realism, Stratified Ontology 


\section{Giriş}

Tüm gözlem faaliyetinin teori yüklü olması ve bilginin kendisinin sosyal ve tarihsel bir ürün olarak kısmi, göreceli ve belirli çıkarları yansıtıyor olması anlamında epistemolojik nesnelliğinin olmaması, sosyal gerçekliğin (ontolojinin) nesnelliğinin de olmamasını zorunlu kılar mı? Postyapısalcıların iddia ettiği epistemolojik ve ontolojik göreceliği esas aldığımızda uluslararası olguları kavramak ve incelemek konusunda yalnızca söylemsel pratiklere dayanabilme görüşü öne çıkmaktadır. Bu makale söylemsel pratiklerin anlamlar sistemlerinin öznelerarası oluşumunu, üretimini ve yeniden üretimini kavramadaki önemli rolüne rağmen, sosyal yapılar ile eşit görülemeyeceği ve söylemlerin ancak farklılaşmış ve katmanlı bir ontoloji içinde kavramsallaştıııldıklarında belirli bir etkinlik kazandıklarını ileri sürmektedir. Makale, sosyal gerçekliği sadece yorumcu şemalar aracıllğıyla bilebileceğimizi ifade eden epistemolojik göreceliğin, sosyal dünyayı söylemsel pratiklerle eşit gören göreceli bir ontoloji kavrayışına götürmek zorunda olmadığını gösterme çabasındadır. Makale, 'söylemsel indirgemeciliğe' düşmeden bir 'ontolojik derinlik' yakalayabilmek için, eleştirel gerçekçiliğin (critical realism) söylem dışı toplumsal yapı kavrayışına dayanır. Bu çerçevede, söylemi gerçekliğin kurucusu olarak görmek yerine, söylemsel inşaların söylem dışı bir referansla dinamik bir biçimde etkileşime girerek meydana geldikleri öne sürülmektedir. Bu doğrultuda, 'ontolojik derinlik' yokluğunda söylemsel pratikler ve inşaların yapısökümü veya rakip yorumlar seviyesinde mahkûm kalacakları gösterilecektir.

Postyapısalcılık "bilimsel nesnelliğe ilişkin tüm bilgi iddialarını, güç pratikleri aracılığıyla belirli bir düzeni zorlayan sosyal pratikler" ${ }^{1}$ indirgemektedir. Söylem dışı bilgi ve gerçeklik iddialarının olanaklılığını reddeden postyapısalcıllğın bu göreceli epistemolojik tutumu, Uluslararası İlişkiler'de (Uİ) farklı yaklaşımlar tarafından eleştirilmiştir. Uİ'de önde gelen inşacı bir yazar olan Pouliot, postyapısalcılığın epistemolojikgöreceliğinden sakınmakiçin aktörler (agents) tarafindan gerçek olarak kabul edilen (nesneleştirilmiş) sosyal olguların, bilgimizi üzerine inşa edebileceğimiz "epistemolojik bir temel” oluşturduğunu belirtmektedir. ${ }^{2}$ Öte yandan, postyapısalcılığın göreceli epistemolojisi dirençle karşılanırken; onun dilini, söylemini veya söylemsel pratiklerini sosyal gerçekliğin kurucu kaynakları olarak gören göreceli ontoloji anlayışının özellikle post-pozitivist çevrelerde oldukça kabul görmesi dikkat çekicidir. ${ }^{3}$ Yine Pouliot’a göre inşacılar için olgusal dünya, bizim onun hakkında sahip olduğumuz ve sosyal olarak inşa edilmiş temsillerimiz dışında bilinemez. ${ }^{4} \mathrm{Bu}$ açıdan hem sahip olduğumuz bilgi hem de sosyal gerçeklik, sosyal inşalar olarak kabul edilmektedir. Sosyal gerçekliğin sosyal bir inşa olduğu tezi ile Shapiro gibi postyapısalcı yazarlara göre ise devlet, çıkarlar, ilişkiler, yapılar gibi sosyal bilimin tüm nesnelerinin sadece dilsel pratikler ve diğer sembolik gösterenler aracılığıyla anlam kazandığı anlaşılmaktadır. Dolayısıyla, uluslararası politikanın ontolojisini meydana getiren bu unsurların söylem dışı herhangi bir anlamı veya varlı̆ğ olamayacağı öne sürülmektedir.5

1 Colin Wight, "Philosophy of Social Science and International Relations”, Walter Carlsnaes et al. (der.), Handbook of International Relations, Londra, Sage, 2013, s. 40.

2 Vincent Pouliot, “The Essence of Constructivism”, Journal of International Relations and Development, Cilt 7, No 3, 2004, s. 320 .

3 Post-pozitivist yaklaşımlar içerisinde özellikle Uluslararası Ekonomi Politik alanında Neo-Gramsciyan bir perspektif benimseyen yazarların söylemsel ontoloji kavrayışına mesafeli durduklarını belirtmek gerekir. Bkz. Andreas Bieler ve David Morton, “The Deficits of Discourse in IPE: Turning Base Metal into Gold?”, International Studies Quarterly, Cilt 52, No 1, 2008, s. 103-128.

4 Vincent Pouliot, “'Sobjectivism': Toward a Constructivist Methodology”, International Studies Quarterly, Cilt 51, No 2, 2007, s. 363.

5 Michael Shapiro, "Metaphor in the Philosophy of the Social Sciences", Cultural Critique, Cilt 2, No 2, 1986, s. 191-214. 
Bu anlayışa göre biz dünyayı yalnızca onu betimlemek için kullandığımız dil aracılığıyla bilmek zorunda kalmıyor, aynı zamanda bir metnin veya ifadenin belirli bir okumasını kurmaya çalıştığımızda, diğer okumaları, bu okumaların zemini olarak kabul ediyoruz. ${ }^{6}$ Bu nedenle, sabit ve değişmez bir zemin veya bilgimizi dayandırabileceğimiz bir temel bulunduğu anlayışı yanıltıcıdır. Bu açıdan, hiçbir zaman bir metnin "hakiki" bir okumasına ulaşamayız; sadece o metnin çoklu ve eşdeğerde olan yorumlarıyla karşılaşabiliriz. Öte yandan, dilin kendisi göreceliyken, bilebileceğimiz tek "hakikat" de dilse, o zaman gerçekliğin dilsel bir gelenek (linguistic convention) veya dilsel bir alışkanlık (linguistic habit) olduğu sonucuna varılabilir. ${ }^{7}$ Buna göre hakikat; söylemsel, dilsel veya öznelerarası pratiklerle eşitlenir. ${ }^{8}$ Bu bağlamda, "metnin dışında hiçbir şey yoktur” (il n’y a pas de hors-texte) şeklindeki Derrida’nın ünlü iddiası, ${ }^{9}$ postyapısalcılığın bilgi (epistemoloji) ve sosyal gerçeklik (ontoloji) arasındaki ilişkisini tanımlayan temel savlarından biri haline gelir.

Yukarıdaki savlar, uluslararası politikanın nelerden oluştuğu ve ne gibi mekanizmalara dayanarak işlediği (ontoloji) ile ilgili soruların, bunların söylemsel olarak nasıl inşa edildiğine bağlı olduğunu ortaya koymaktadır. Sosyal gerçekliği kavramsallaştırma konusunda göreceli epistemolojik vurguyu esas aldığımızda, uluslararası politikanın ontolojisini oluşturan aktörlerin, yapıların ve aralarındaki ilişkilerin ancak söylemsel bir varlığı olduğu sonucuna ulaşılır. ${ }^{10} \mathrm{Bu}$ anlamda söylemsel pratikler inceleme faaliyetinin başlangıç ve bitiş noktasını oluşturacakları için, bu pratiklerin kendilerinin daha derin bir sosyal bağlam tarafından şekillendirilmiş olabilecekleri ihtimali teorilerin kapsamı dışına itilir. Bu durum araştırma faaliyetinin önceden sınırlandırılması gibi bir sonucu beraberinde getirir. $\mathrm{Bu}$ konuda, postyapısalcılığın güç-bilgi ilişkisi ve söylemin pratiği meşrulaştırarak şekillendirdiği vurgusu bulunmakla birlikte, bu sürecin geçmişten gelen ve yapılandırılmış söylem dışı bir referansla gerçekleştiği hususu genelde göz ardı edilmektedir. Diğer bir deyişle, postyapısalcılık sadece söylem üzerinde durmaz. Daha ziyade, güç-bilgi ilişkilerinin pratiği nasıl meşrulaştırdığı ve yeniden ürettiği ile de ilgilenmektedir. Bununla birlikte, özellikle Uİdeki postyapısalcılar, bilgi-iktidar kavrayışının, ontolojik düzlemdeki söylem dışı alan bilgisiyle nasıl ilişkilendirilebileceği üzerine eğilmeme veya daha geniş sosyal bağlamı göz ardı etme eğiliminde olmuşlardır. ${ }^{11}$ Öznelerarası anlamların kurulması (söylemsel inşalar) sosyal yaşamın önemli bir yönünü oluştursa da, sosyal gerçeklik söylemsel pratiklere indirgenemez. "Metinler hem sosyal olarak yapılandırmacı hem de sosyal olarak yapılandırılmış oldukları için, sadece metinlerin anlam üretme biçimini değil...aynı zamanda anlam üretiminin kendisinin sosyal yapının oluşumsal ve semiyotik olmayan özellikleri ile nasıl kısıtlandığını incelemeliyiz." ${ }^{12}$

6 Emanuel Adler, "Seizing the Middle Ground: Constructivism in World Politics", European Journal of International Relations, Cilt 3, No 3, 1997, s. 321-322.

7 Pauline Rosenau, Post-Modernism and the Social Sciences, New Jersey, Princeton University Press, 1992, s.182.

8 Matthew Fluck, "Truth, Values and the Value of Truth in Critical International Relations Theory", Millenium, Cilt 39, No 1,2010 , s. 260.

9 Jacques Derrida, Of Grammatology, Baltimore, Johns Hopkins University Press, 1997, s. 158.

10 Örneğin, Hansen'in ifadesiyle "Kimlik, devletlerin veya diğer kolektifliklerin, dış politikayı sunma ve uygulamada kullandıkları söylemsel pratiklerden bağımsız olarak sahip olduğu bir şey değildir.” Lene Hansen, Security as Practice: Discourse Analysis and the Bosnian War, New York, Routledge, 2006, s. 1.

11 Örneğin, Foucault'nun kendisi, "Arkeoloji ayrıca söylemsel ilişkiler ve söylemsel olmayan alanlar (kurumlar, politik olaylar, ekonomik uygulamalar ve süreçler) arasındaki ilişkileri de ortaya koymaktadır” iddiasında bulunmuştur. Michel Foucault, The Archaeology of Knowledge, Londra, Routledge, 2002, s. 179-180.

12 Norman Fairclough et al., "Critical realism and semiosis", Jonathan Joseph ve John Michael Roberts (der.), Realism Discourse and Deconstruction, New York, Routledge, 2004, s. 27. 
$\mathrm{Bu}$ makalenin amacı post-pozitivist çevrelerde yaygın bir geçerlilik kazanmış olan sosyal gerçekliği söylemsel veya dilsel pratiklere indirgemekle ilgili postyapısalcılığın realizm karşıtı ontolojik varsayımlarına eleştirel bir inceleme sunmaktır. Makale, söylemsel pratiklerin, sosyal gerçekliği kurdukları ve bu nedenle söylem/metin dışında bilimin nesneleriyle ilişkin bilginin olamayacağı savlarını; eleştirel gerçekçilik bilim felsefesi perspektifinden sorgulamaktadır. Gerçeklik ile ilgili önermelerin bilgi ile ilgili önermelere indirgenemeyeceğini savunan eleştirel gerçekçilik, öznelerarası anlamlar ve söylemsel pratikler dışında nesnel bir gerçeklik bulunduğu iddiasıyla yorumsamacılıktan ayrılırken; gerçekliği doğrudan gözlemlenen ampirik düzenliliklere indirgemesi nedeniyle gerçekliğin katmanlaşmış doğasını göz ardı eden 'ampirik realizmden' (pozitivizmden) de ayrılmaktadır. Makale ayrıca eleştirel gerçekçiliğin 'katmanlı ontoloji' (stratified ontology) kavrayışının söylemsel pratiklerin neden ve hangi koşullarda belirli bir şekilde ortaya çıktığını anlamak konusunda da yararlı bir yaklaşım sunduğunu göstermeye çalışmaktadır. Bu amaçla, postyapısalcılığın teori ile sosyal gerçeklik arasında kurduğu kusurlu ilişki incelemenin odağına oturtulacaktır. Çalışma ilk önce postyapısalcılık ile yapısalcılık arasındaki karmaşık ve çelişkili ilişkinin irdelemesiyle başlamaktadır. Burada özellikle söylemsel pratikler ve yapı arasında varsayılan ilişki sorunsallaştırılacaktır. Ardından postyapısalcılığın söylemsel epistemolojik kaygılarının postyapısalcılığın farklılaşmamış, düz bir ontolojiye yol açtığı ve bu yönelimin nesnel sosyal yapıların kavramsallaştırılmasını dışladığı için sosyal teoriyi bir çıkmaza soktuğu iddia edilecektir. Buna karşı katmanlı bir ontoloji kavrayışının, bilginin sosyal ve tarihsel yönünü kabul ederken, bilgimizin söylem dışı bir referansla sürekli yanlışlandığı ve derinleştiği ortaya konularak, sosyal yapıları ve söylemsel pratikleri birbirleriyle birleştirmek yerine, aralarında nasıl bir ilişki kurulabileceği ile ilgili önemli imkânlar sunduğu gösterilmeye çalışılacaktır.

\section{Postyapısalcılık-Yapısalcılık İlişkisi: Özne Kaybından Yapı Kaybına}

“Öznenin merkezi konumdan uzaklaştırılmasının” postyapısalcılığın esas özelliklerinden olduğu sıkça dile getirilirken, ${ }^{13}$ postyapısalcılığın yapı kavramını söylem kavramı lehine terk etme isteği genelde göz ardı edilir. Sosyal teori ve dilbilimdeki yapısalcılı̆̆ın genel bir eleştirisi olarak ortaya çıkan postyapısalcılık, yapısalcı düşünce geleneğinin sosyal yapıların nesnel bir bilimini ortaya koyma çabalarına karşı bir tepki biçiminde gelişmiştir. Yapısalcı yazarlar arasında önemli farklılıklar olduğunu dikkate aldığımızda, burada tek bir 'yapısalcılık' yaklaşımından bahsetmek yerine farklı yapısalcı geleneklerden bahsedilmesi gerektiğini hatırlamakta yarar vardır. Sosyal teoride yapısalcılık Kıta Avrupa geleneği (Durkheim, Althusser) ile Amerikan Yapısal (İşlevsel) Sosyolojisi (Parsons, Merton) arasında bölünmesi yanında, dilbilimde Sassure'nin çalışmalarıyla ve dilsel kategorileri antropolojiye aktaran Levi-Strauss'un çalışmalarıyla ilişkilendirilmektedir.

Durkheim'ın izinden giden yapısalcı yaklaşımlardan farklı olarak Levi-Strauss sosyal yapıları zihinsel inşalar olarak kabul etmektedir. Levi-Strauss'un bu görüşü aslında, yapısalcı gelenek içinde bir istisnadır, çünkü sosyal yapıların varlığını reddeden ve tüm sosyal ilişkilerin insanların düşüncelerinde ve bu düşünceler aracılığıyla vücut bulduğunu söyleyen Peter Winch'in metodolojik bireyciliğinin yorumsamacı perspektifiyle örtüşmektedir. ${ }^{14}$ Bununla beraber, önemli farklılıklarına rağmen yapısalcıların çalışmalarında öne çıkan bazı ortak göstergelerin olduğunu da eklemek durumundayız. Yapısalcılar, sosyal eylemin anlaşılabilmesi ve açıklanabilmesi için dikkatimizi bireysel öznelcilikten

13 Jenny Edkins, Poststructuralism and International Relations, Boulder, Lynne Rienner, 1999, s. 21.

14 Mario Bunge, Treatise on Basic Philosophy Volume 4: Ontology II, Dordrecht, D. Reidel Publishing Company, 1979, s. 234. 
kaydırıp sosyal pratiklerin şekillendirildiği yapısal koşullara ve düzenleyici ilkelere odaklanmamız gerektiğini savunmuşlardır. ${ }^{15} \mathrm{Bu}$ açıdan yapısalcılık, fenomenlerin tekil öğelerine ayrılarak aktörlerin davranışları veya onların kendi eylemleri hakkında sahip oldukları düşünceler açısından incelenmesi gerektiğini savunan metodolojik bireyciliğe getirdiği eleştiri ile öne çıkmaktadır. Keat ve Urry’ye göre "yapının oluşturucu öğeleri arasındaki ilişkinin; onun tekil, bireysel öğelerinden daha önemli olduğu ve bu öğelerin kendilerinin de ilişkiler setinden ibaret olduğu anlayış» yapısal analizlerin ortak bir özelliğidir. ${ }^{16}$ Walker’a göre yapısal analiz, genellikle olguların yüzeysel olarak aldıkları biçimleri açıklama ve görünümlerin altında yatan derin yapıların veya evrensel ilkelerin bilgisini üretme çabasıyla ilişkilendirilmektedir. ${ }^{17}$

Postyapısalcıların önemli bir kısmı, Foucault’nun ilk çalışmalarında olduğu gibi, yapısalcılık geleneğine yakın bir biçimde bireyi anlamın kaynağı ve sosyal olguları açıklamanın doğal merkezi olarak gören öznelciliğe mesafeli durmaktadır. ${ }^{18} \mathrm{Bu}$ şekilde, postyapısalcılık bireysel eylem ve bilince odaklanmasını gerektiren 'özgür' özneye ilişkin kuşkucu yapısalcı tutumdan beslenerek, aktörlerin özneliğine dayanan bir araştırma biçiminden uzak durur. Bununla beraber, yapısalcı gelenekte öznenin, maddi veya nesnel bir gerçeklik biçimine tekabül eden toplumsal ilişkiler ve kolektif temsiller (Durkheim), üretim ilişkileri (Althusser) veya düzenli ve sürekli kurumsal ilişkiler seti (Parsons) tarafından kısıtlandığı ve belirlendiği varsayılırken, postyapısalcı düşüncede öznenin belirli söylemsel pratikler tarafından inşa edildiği varsayılmaktadır. Sassure'nin ve Levi-Strauss'un yapısalcılığında tüm ilişkiler dilsel, sembolik ve söylemsel olarak (içsel ilişkiler biçiminde) kabul edildiği için öznenin de bu dilsel pratikler aracılığıyla kurulduğu düşüncesine ulaşılmaktadır. ${ }^{19}$ Sassure'nin yapısalcılık açısından önemi, kelimelerin taşıdığı anlamın onların dışsal bir nesneye atıfla değil, bir sistemin (dilin) diğer bileşenleri arasında bulunan farklılıklara ve karşıtlıklara bağlı olarak belirlendiğini ortaya koymasıdır. ${ }^{20}$ Diğer bir deyişle, anlam kelimelerin bir özelliği veya kelimelerin nesnelere atfettiği bir ifade açısından değil, diğer kelimelerle olan ilişkileri açısından tanımlanmaktadır. ${ }^{21} \mathrm{Bu}$ açıdan sosyal dünya ve hakikat hakkındaki bilgimiz, bireysel insan öznesinin çevreye ve davranışlarına atfettiği anlamlar açısından tanımlanamaz; Foucault'nun deyimiyle, "öznelerin konumu, algılama kapasiteleri ve pratik imkânları," "onlara hükmeden ve hatta onları boğan" ${ }^{22}$ belirli süreçleri ve koşulları önceden varsaymaktadır. ${ }^{23}$ Postyapısalcılara göre nasıl ki sözcüklerin sabit ve kesin anlamları yoksa, aynı şekilde özne de sürekli bir inşa ve oluşum sürecinde olduğundan hiçbir zaman ontolojik bir bütünlüğe erişemeyen parçalı, akışkan ve rastlantısal bir niteliğe sahiptir. Bu anlamda özne sadece onu oluşturan söylem içinde var olabildiği ve anlamlandırabileceği için, özne gerçek anlamda var olamaz. ${ }^{24}$ Onun yerine sadece özne

15 Russel Keat ve John Urry, Bilim Olarak Sosyal Teori, Ankara, İmge, 2016, s. 192.

16 Ibid., s. 192.

17 R.B.J Walker, "History and Structure in the Theory of International Relations", Millennium, Cilt 18, No 2, 1989 , s. 172.

18 David Layder, Understanding Social Theory, Londra, Sage, 2006; Michael Foucault, The Order of Things, New York, Routledge, 2002.

19 Madan Sarup, An Introductory Guide to Post-structuralism and Postmodernism, New York, Harvester Wheatsheaf, 1993, s. 73; Claude Levi-Strauss, Structural Anthropology, New York, Basic Books, 1963, s. 277-315.

20 David Howarth, Poststructuralism and After: Structure, Subjectivity and Power, New York, Palgrave, 2013, s. 9.

21 Alex Callinicos, "Postmodernism, Post-Structuralism, Post-Marxism?”, Theory, Culture \& Society, Cilt 2, No3, 1985, s. 89; Ferdinand De Saussure, Course in General Linguistics, New York, Philosophical Library, 1959.

22 Foucault, The Order of Things, s. xiv.

23 Howarth, Poststructuralism and After, s. 9.

24 Jenny Edkins ve Veronique Pin-Fat, “The Subject of the Political”, Jenny Edkins, et al. (der.), Sovereignty and Subjectivity, Boulder, Lynne Rienner, 1999, s. 1. 
söylemlerinden bahsedilebilir. Bu nedenle, postyapısalcılık “kimlik karşıtı bir kimlik söylemi” olarak da tanımlanmıştır. ${ }^{25}$

Postyapısalcı analizin merkezinde bireysel özne değil, söylemsel pratikler mevcuttur. Söylemsel pratikler, söylemenin yapmak anlamına geldiğini ifade eden sosyal olarak anlamlı konuşma eylemleri (söz edimleri - speech acts) olarak tanımlanabilir. ${ }^{26}$ Foucault kendi çalışmalarında insanların belirli söylemsel pratikler aracılığıyla nasıl özne haline getirildiğinin tarihini ortaya koymaya çalıştığını vurgulamaktadır. ${ }^{27}$ Bazı yazarlar, bu geçişte Althusser' in tarihin “öznesiz bir süreç” olduğu ve öznenin kendisinin ideoloji tarafından kurulduğu düşüncesinin önemini vurgular. ${ }^{28}$ Postyapısalcılar ise sınıfsal veya söylem dışı bir gerçeklik çağrışımı yaptığı gerekçesiyle, ideoloji kavramı yerine dilsel ilişkilere atıfta bulunan söylem veya metin kavramlarını benimsemeyi tercih eder. Mouzelis'in belirttiği üzere bu bakışa göre, söylemsel pratiklerin ister sınıf isterse seçkinler veya çıar grupları olsun belirli bir yaratıcısı yoktur. Bu anlamda, toplumsal düzenin belirli bir kurucusu veya amacı olmadığı için, toplumsal olan (the social) tutarlılıktan yoksun bir biçimde sadece farklılık söylemlerinden oluşmaktadır. ${ }^{29}$ Derrida'nın ifadesiyle "bir merkezin ya da kökenin olmadığı bir durumda, her şeyin söylem haline dönüştügü andır.” ${ }^{30} \mathrm{Bu}$ aynı zamanda yapısalcılıktan postyapısalcılığa geçişi en açık biçimde gösteren argüman olarak anlaşılabilir.

Perry Anderson’un dikkatimizi çektiği üzere, “yapılar her türlü özneden yoksun, tümüyle kendi faaliyetlerinde bırakıldıklarında onları yapılar olarak 'tanımlayanı' yitireceklerdir - yani örgütlenmenin her türlü nesnel koordinatını...” Anderson'un isabetli ifadesiyle, “yapı, böylelikle, kendi antitezine yıkılır ve asıl postyapısalcılık ya da öznesiz öznelcilik (subjectivism without a subject)” doğmuş olur. ${ }^{31}$ Böylece postyapısalcılık, bir yandan özneyi merkezi konumundan uzaklaştırma çabasını içerirken, diğer yandan sosyal yapıları dilsel pratiklere, söyleme veya metne indirgeme girişimini ifade etmektedir. Postyapısalcı literatürde yapı, sosyal kurumlar, söylem, söylemsel pratikler ve metin gibi kavramların birbirlerinin yerine kullanılma veya onları birbirine indirgeme eğilimi öne çıkmaktadır. Postyapısalcılara göre sosyal kurumlar, "metin yoluyla yaratılan varlığının ötesinde, ontolojik statüsü veya epistemolojik önemi olmayan söylemsel inşalar ve kültürel biçimler”dir. ${ }^{32} \mathrm{Bu}$ açıdan Westwood ve Linstead'e göre:

"yapı fikri, yalnızca kaygan ve değişen metinsel ilişkilerin akışı yerine oturmuş gibi davranan ideolojik bir uygulamayı temsil eden bir yanılsamadır... Yapı, doğal hareket ve akış üzerine bir düzen ve sabitlik empoze etmek için tasarlanmış bir uygulama veya bir kapatma stratejisidir. Yapı, anlamın dondurulması, örgüt metninde göstergelerin oynamasına getirilen bir kısıtlama, anlamın biçim ile nötrleştirilmesidir." ${ }^{33}$

25 Richard Ned Lebow, “IR Theory as Identity Discourses”, Ken Booth ve Toni Erskine (der.), International Relations Theory Today, Cambridge, Polity Press, 2016.

26 Emanuel Adler ve Vincent Pouliot, "International Practices”, International Theory, Cilt 3, No 1, 2011, s. 16.

27 Michael Foucault, “The Subject and Power”, H. L. Dreyfus ve P. Rabinow (der.), Michel Foucault, Brighton, 1982, s. 208.

28 Callinicos, "Postmodernism, Post-Structuralism, Post-Marxism?", s. 87.

29 Nicos Mouzelis, Sociological Theory: What Went Wrong?, New York, Routledge, 1995, s. 45.

30 Jacques Derrida, Writing and Difference, Londra, Routledge, 2002, s. 354.

31 Perry Anderson, In the Tracks of Historical Materialism, Chicago, The University of Chicago Press, 1984, s. 54.

32 Michael Reed, "Reflections on the 'Realist Turn' in Organization and Management Studies", Journal of Management Studies, Cilt 42, No 8, 2005, s. 1622.

33 Robert Westwood ve Stephen Linstead, “Language/organization: Introduction”, R. Westwood ve S. Linstead (der.), The Language of Organization, Londra, Sage, 2001, s. 4-5. 
$\mathrm{Bu}$ anlamda kurumlar ve örgütler sadece dilin bir etkisi olarak algılandıkları ölçüde bir 'yapı' olabilir. Westwood’a göre kurumlar ve örgütler sadece bir metin içinde var olabilir. ${ }^{34}$ Diğer bir deyişle, söylemsel inşalar dışında örgüt diyebileceğimiz yapılar, sınırlar veya bürokratik nesneler yoktur. Daha ziyade yapılar güç-bilgi ilişkisi içinde değişir, dönüşür veya yeniden üretilirler. ${ }^{35} \mathrm{Bu}$ anlamda kurumların ve örgütlerin onları oluşturan metin dışında özerk, istikrarlı veya yapısal statüleri yoktur. Öte yandan, metnin de bir mevcudiyeti yoktur: metnin kendisi dinamik farklılık ilişkileri içinde değişken bir gösterenler (signifier) ağından oluşmaktadır. Kısacası metin, anlamların dağınık olduğu bir süreçtir. ${ }^{36}$

Uİde Doty ve Weldes gibi postyapısalcı ontolojiyi paylaşan yazarlara göre, yapı kavramı, metne veya dile indirgenmediği durumlarda bile, sadece pratiklerden veya söylemden ibarettir. ${ }^{37}$ Örneğin, Laffey ve Weldes'e göre söylem, hem dilsel hem de dilsel olmayan pratikleri içerir. ${ }^{38}$ Pratikler bu anlamda sosyal yaşamın öznelerarası doğasını yansıtan, anlamlar yüklü davranışlar ve sosyal açıdan anlamlı eylem örüntüleridir. ${ }^{39} \mathrm{Bu}$ anlamda söylem kavramı, "dilsel ve dilsel olmayan pratiklerin kullanılması aracılığıyla her zaman açık ve tamamlanmamış olan anlamlar sistemlerinin öznelerarası üretimine, yeniden üretimine ve başkalaşmasına işaret eder." ${ }^{40}$ Sosyal teoride en önemli tartışmaların başında gelen yapı-yapan (structure-agent) sorunsalının, ancak postyapısalcı (Derrida'cı) bir okuma ile kavranabileceğini ileri süren Roxanne Doty, yapı-yapan ontolojisinin pratiklerin belirsizliği (indeterminacy of practices) ile değiştirilmesini önerir. Doty'e göre özne veya aktör belirleyici değildir. Daha ziyade özne özerk pratikler tarafından oluşturulmuş ve belirlenmiştir. ${ }^{41} \mathrm{Bu}$ anlamda, hem yapı hem de eylemliliği ifade eden aktör veya yapanlık ( agency) da rastlantısal, istikrarsız ve söyleme veya söylemsel pratiklere bağlıdır. Öte yandan, Doty’ye göre, burada belirlenimcilik (determinism) suçlamasını durduran şey, belirleyici olan pratiklerin kendilerinin radikal bir biçimde belirsiz ve rastlantısal (contingent) olmasıdır. ${ }^{42}$ Ancak Wight' ın isabetli bir biçimde belirttiği gibi "bu tutum, geleneksel yapısalcı açıklamaların belirlenimciliğini, postyapısalcılığın yeni bir 'belirsiz belirlenimciliği' (indeterminate determinism) ile değiştirir.”33 Bu şekilde Doty'nin yapı-yapan sorunsalına sunduğu çözümde, yapı ve aktör, söylemsel pratiklerin bir yan etkisine indirgendiği için yapı-yapan sorunsalı çözülmekten ziyade yeni bir söylem ile örtülmektedir.

Söylemsel bir ontolojiyi paylaşan yazarlar, akış içinde olan şeylere sahte bir sabitlik bahşettiği gerekçesiyle, yapı kavramı başta olmak üzere 'nesne' kavramının kendisini bile reddetme eğilimindedir. ${ }^{44} \mathrm{Bu}$ açıdan, postyapısalcılık temelde "yapı kavramını ve bilimsel nesnel 'hakikat'

34 Ibid., s.4.

35 Bu noktaya dikkatimi çeken anonim hakeme teşekkür ederim.

36 Westwood ve Linstead, "Language/organization", s. 4.

37 Roxanne Lynn Doty, "Aporia: A Critical Exploration of the Agent-Structure Problematique in International Relations Theory”, European Journal of International Relations, Cilt 3 No.3, 1997, s. 365-392.

38 Mark Laffey ve Jutta Weldes, "Methodological Reflections on Discourse Analysis", Qualitative Methods, Cilt 2, No 1, 2004, s. 28.

39 Pouliot, “The Essence of Constructivism”, s. 330.

40 Eric Herring ve Doug Stokes, "Critical realism and historical materialism as resources for critical terrorism studies", Critical Studies on Terrorism, Cilt 4, No 1, 2011, s. 6.

41 Doty, "Aporia: A Critical Exploration of the Agent-Structure Problematique", s. 379.

42 Ibid., s. 377.

43 Colin Wight, Agents, Structures and International Relations, New York, Cambridge University Press, 2006, s. 82.

44 Kathryn Dean et al., "Realism, Marxism and Method", Kathryn Dean et al., Realism, Philosophy and Social Science, New York, Palgrave, 2006, s. 1. 
arayışını reddeden” bir tutum benimser. ${ }^{45}$ Özetle postyapısalcılık, sosyal olguları incelerken aktörlerin özneliğine geri dönmeden, nesnel toplumsal yapıların varlığını reddetmesi şeklinde tanımlanır. Sonuç olarak, postyapısalcıların insan özne eleştirisi dışında yapısalcılığın, bilime ve rasyonaliteye gösterdiği bağlılığı başta olmak üzere, birçok kabulünü reddettiklerini söyleyebiliriz. ${ }^{46}$ Burada Foucault'nun son dönemdeki kendi çalışmalarını "yapısalcı" veya "postyapısalcı" değil "anti-yapısalcı" olarak tanımladığını hatırlamakta yarar vardır. ${ }^{47}$

\section{Dilin Yörüngesinden Çıkarılması veya Ontoloji-Epistemoloji Karmaşası}

Anderson, Sassure'nin dilbilimde geliştirdiği kavramlarının ve yönteminin diğer disiplinlerde istismarcı bir biçimde kullanıldığına dikkat çekmiştir. Bu durum, Anderson tarafından "dilin yörüngesinden çıkarılması” (exorbitation of language) olarak tanımlanmaktadır. ${ }^{48}$ İnşacı bir sosyolog olan Steve Woolgar, Foucault'nun söylem anlayışının, belirli bir dünya görüşünü oluşturan etkinliklerin, olayların, koşulların ve nesnelerin bir bütününü gösterdiğini belirtmektedir. Bu açıdan nesneler ve koşullar gibi varlıklar, birer metin olarak ele alınabilir, çünkü onlar da bir söylemi ortaya koyar. Woolgar'a göre postyapısalcılığın bu söylem kavrayışı, gerçekliği anlamak için kullanılan "kelimelerden (metinler, işaretler, belgeler vb.) bağımsız bir gerçekliğin olmadığını savunan etnometodolojinin idealist kanadının duruşuyla uyumludur. Diğer bir deyişle, gerçeklik söylem içinde ve onun aracıllğıyla oluşur." ${ }^{* 9}$ Benzer bir biçimde, Richard Rorty, sosyal gerçekliğin veya dünyanın onunla ilgili konuşmalarımızdan bağımsız olarak var olmadığı, söylemlerle oluşturulduğu fikrini "metinselcilik" olarak tanımlamaktadır. ${ }^{50} \mathrm{Bu}$ anlamda postyapısalcılığı Alman klasik idealizminin mirasçısı olarak gören Rorty'ye göre, postyapısalcılık, kültürün merkezine bilim yerine felsefeyi koymak isteyen 19. yüzyıl idealizminden farklı olarak, hem bilimi hem de felsefeyi birer "edebiyat/yazı türü" (literary genre) olarak ele alarak, kültürün merkezine edebiyatı veya metinleri yerleştirmek isteyen 20. yüzyılın idealizmine işaret etmektedir. ${ }^{51}$ Bunge'ye göre, postmodern yaklaşımlar, nesnel gerçeklerin bulunabilme olanaklılığını reddederek, tüm akademik disiplinleri birer anlatı veya söylem olarak değerlendirmektedir. Bir başka deyişle, akademik disiplinler ve teoriler bilimden ziyade edebiyatın bir türü sayılarak, sınamadan çok birer tercih meselesi haline gelmektedir. $^{52}$

Mark Bevir'e göre, gerek Sassure’nin yapısalcılı̆̆ı, gerekse postyapısalcılık dilin (öznelerden ve toplumsal ilişkilerden bağımsızlaşması anlamında) şeyleştirilmesine (reification) yol açmaktadır. Her ikisi de anlamın, aktörlerin kelimeleri kullandıkları biçiminden değil, dilsel birimler arasındaki farklılık ilişkilerinden ortaya çıtığını savunur. Bu şekilde dil, insan öznelerin eylemlerinden ayrı bir biçimde anlam üreten şeyleştirilmiş bir semiyotik koda dönüşmektedir. Artık şeyleştirilmiş dil,

45 Layder, Understanding Social Theory, s. 64.

46 Wight, "Philosophy of Social Science and International Relations", s. 34.

47 Foucault, "Truth and Power", s. 114.

48 Anderson, In the Tracks of Historical Materialism, s. 40-41.

49 Steve Woolgar, "On the Alleged Distinction between Discourse and Praxis", Social Studies of Science, Cilt 16, No 2, 1986, s. 312.

50 Richard Rorty, Consequences of Pragmatism, Minneapolis, University of Minnesota Press, 1982, s. 140-141.

51 Ibid., s. 141.

52 Mario Bunge, Chasing Reality: Strife over Realism, Toronto, University of Toronto Press, 2006, s. 16-17. 
bireysel aktörlerin anlamlarını, inançlarını ve böylelikle eylemlerini belirler duruma geldiği için, dilsel bir belirlenimcilik ile karşı karşıya kalırız. ${ }^{53}$ Diğer bir deyişle, "eğer bireyler kendilerine verilen sosyal bir söylemle kendilerini basitçe inşa ettiyse, bu söylemleri değiştirme kapasitesinden yoksun olmaları” gerektiği gözükmektedir. ${ }^{54}$ David McNally'nin ifadesiyle "dilimiz, ya da 'söylem'imiz, ya da 'metin'imiz ... bildiklerimizi, yapabildiklerimizi tanımlar ve sınırlar." ${ }^{55} \mathrm{Bu}$ şekilde söylem her şeyi söylemsel olanın içine çeken ve yutan bir öze dönüşmektedir. ${ }^{56}$

\section{Sosyal Bağlamın Dile Eritilmesi: Sosyal Teoriyi Etkisizleştirme Pratiği Olarak Postyapısalcılık}

Postyapısalcı düşüncenin 1980 'lerden itibaren akademik çevrelerde yaygınlaşması, ${ }^{57}$ Pijl'e göre, önemli ölçüde o dönemde başlatılan ve günümüz hâkim ideolojisini şekillendiren, neoliberal ekonomik politikalar uygulamalarının öne çıkardığı bireycilik ile yakından ilişkilidir. ${ }^{58}$ Jonathan Joseph'in belirttiği gibi, postyapısalcı literatürde öne çıan sosyal olguların biricikleştirilmesi ve "siyasal sorunların bireyselleştirilmesi" stratejisi, "neoliberalizmle mükemmel uyum sağlar" çünkü bu tutum "kolektif siyasete, devlete, siyasi partilere, sendikalara ve geleneksel olarak toplumsal dönüşüme yardımcı olan diğer toplumsal güçlere saldırarak statükoyu güçlendirmeye yardımcı olur." ${ }^{59}$ Rosenau'nun isabetli ifadesiyle postyapısalcılı̆̆ın "bürokrasi karşıtı tutumu - hiyerarşiye, devlet iktidarına ve idari rejimlere karşı oluşu - de-regülasyon, özelleştirme ve sosyal yardımların azaltılması gibi” özgül neoliberal politikalarla birlikte gider. ${ }^{60} \mathrm{Bu}$ çerçevede öne çıkan "bireysel olan ve sosyal olan arasında bir boşluk bulunmadığı düşüncesi, sosyal ilişkilerin belirleyiciliğini bireyler arasındaki rastlantısal ilişkilere indirgemektedir” ${ }^{61}$ Diğer bir deyişle, sosyal olanın sadece söylemsel bir gerçekliğe sahip olduğu fikri, temel toplumsal ilişkilerin yaşam tarzı seçimleriyle eşdeğer olarak görülmesine yol açmaktadır. "'Sosyal olan', bu açıdan bir bireyin verebileceği belirli bir karardan başka bir şey ifade etmezken; 'toplum', bireysel ilişkilerin toplamına indirgenmiş olmaktadır.”2 Postyapısalcılıkta, sosyal yapılar dilde eritildiği için toplumsal ilişkilerin yerini "konjonktürler" ve yan yana gelişler almaktadır. ${ }^{63}$ Böylece açılanacak tarihsel koşulların, ilişkilerin ve süreçlerin yerini "tarihin rastlantısallaştırılması" almaktadır. $^{64}$

53 Mark Bevir, The Making of British Socialism, New Jersey, Princeton University Presss, 2011, s. 10-11.

54 Ibid.

55 David McNally, “Dil, Tarih ve Sinıf Mücadelesi”, Ellen Meiksins Wood ve John Foster (der.), Marksizm ve Postmodern Gündem, Ankara, Ütopya, 2001, s. 39.

56 Bieler ve Morton, “The Deficits of Discourse in IPE”, s. 114.

57 Postyapısalcılık ve neoliberal küreselleşme arasındaki ilişki üzerine dikkatimi çeken Prof. Dr. İlhan Uzgel’e teşekkür ediyorum.

58 Kees van der Pijl, A Survey of Global Political Economy, Centre for Global Political Economy, University of Sussex, 2009, s.253. Bir düşünce hareketi olarak postyapısalcılığın, ideolojinin ve siyasetin maddi temelinden özerkliğini savunan ve toplumsal dönüşüm konusunda entelektüellere öncü bir rol atfeden 1960'lardaki öğrenci hareketleri bağlamında ortaya çıkması bir rastlantı değildir. Bkz. Ellen Meiksins Wood, The Retreat From Class, Londra, Verso, 1998, s. 75-76.

59 Jonathan Joseph, The Social in the Global: Social Theory, Governmentality and Global Politics, New York, Cambridge University Press, 2012, s. 254.

60 Rosenau, Post-Modernism and the Social Sciences, s. 253.

61 Kenan Malik, The Meaning of Race, New York, NYU Press, 1996, s. 253.

62 Ibid., s. 251.

63 Wood, The Retreat from Class, s. 62.

64 Anderson, In the Tracks of Historical Materialism, s. 48. 
Postyapısalcı görüş bazen açık bazen de örtük bir biçimde, 'kültür' veya 'söylem'in, yani kolektif düşüncelerin toplumsal ve siyasi hayatı oluşturduğunu ve belirlediğini iddia etmiştir. ${ }^{65}$ Dünya veya sosyal gerçeklik, söylemsel ve sembolik olarak 'inşa edilmiş' kabul edildiği için, gerçek ile sahte, hakikat ve kurgu arasındaki sınırlar bulanıklaşır ve istikrarsızlaşır. ${ }^{66}$ Böyle bir durumda, Malik'in ifadesiyle "kültürel olan, maddi olana dönüşürken, bu sefer de ideolojik olan gerçeğin yerini almaktadır. Dil ve söylem, var olan tek gerçek olarak şeyleştirilirken, 'sosyal varlıklar' yanılsama haline gelir, yani dil ve sembol dünyasında oluşturulan şeylere dönüşür." ${ }^{67}$

Elder-Vass'ın dikkatimizi çektiği gibi, eğer tüm bilgi sosyal bir inşa ise ve gerçekliğe sadece onun hakkındaki inançlarımız aracılığıyla erişebilirsek, sosyal olarak inşa edilmemiş hiçbir şey yoktur. Diğer bir deyişle, gerçeklik olarak düşündügümüz şey, aslında sosyal olarak inşa edilmiş bir dizi inançtan başka bir şey değildir. ${ }^{68} \mathrm{Bu}$ çerçevede, gerçeklik sadece söylemsel bir biçim olduğundan, ne ekonominin ne de toplumun veya siyasi sistem gibi sosyal varlıkların var oluşundan bahsedilebilir. Yalnızca ekonomik, sosyal, kültürel ve siyasi 'söylemler'den bahsedilebilir. ${ }^{69}$ Toplumsal olguların söylem içinde eritilmesi (uluslararası) siyasetin maddi boyutundan veya temelinden koparılmasıyla ve ekonomik olgularla politik olgular arasında karşılıklı ilişkinin ortadan kaldırılmasıyla sonuçlanmaktadır. Halliday’in belirttiği gibi, postyapısalcılığın toplumun ve gücün kuruluşunda “söylem”in (kelimelerin, anlamların, sembollerin, kimliklerin ve iletişim biçiminin) rolünü vurgulaması, tarihsel olguların açıklanmasında söylemsel ve ideolojik faktörlerin toplumdaki üretim ilişkileri ve toplumsal ilişkiler gibi daha maddi süreçler ile ilişkilerinin ihmal edilmesine yol açmıştır. ${ }^{70}$ Üstelik nedensel açıklamanın olanaklılığını reddeden bu yaklaşımlar, dünyayı tecrübe etme biçimlerine odaklanan sığ bir sosyal ontolojiyi teşvik ederek, toplumun daha derin bir yapıya sahip olduğunu inkâr eder. ${ }^{71}$ Öte yandan, postyapısalcılar söylemlerin tarihselliğini vurgulargibi görünseler de temelde tarihdışı bir tutum benimser. McNally'nin ifadesiyle: "Tarih onlara, somut toplumsal ilişkiler içinde yaşayan canlı insanlar arasındaki etkileşimler ve çatışmalar tarafından üretilen dinamik bir süreç gibi değil, bir dizi söylemsel 'farklılık', birbiriyle bağlantısız bir dilsel paradigmalar ardışıklı̆ğ gibi görünür.”72

\section{Sosyal Gerçekliğin Söylemsel Pratiğe İndirgenmesi: Ontolojide Farksızlaşma Problemi}

Postyapısalcılık, Wenger'in ifadesiyle "çoğunlukla epistemolojik eleştiri yoluyla ilerlemeyi seçse bile kökeninde, gerçekliğin doğası hakkında gömülü argümanlar içeren bir ontolojik taban içerir.”’3 Postyapısalcı yaklaşımların ontolojisi, onların bulanık ifadelerinde ve dil oyunlarında gizlenmektedir. ${ }^{74}$ Postyapısalcı ontoloji, sosyal açıdan parçalara ayrılmış ve tecrit edilmiş bireylerin dünyasının

65 Aijaz Ahmad, In Theory: Classes, Nations, Literatures, Londra, Verso, 2000, s. 41.

66 Joseph, The Social in the Global, s. 10.

67 Malik, The Meaning of Race, s. 250.

68 Dave Elder-Vass, The Reality of Social Construction, New York, Cambridge University Press, 2012, s. 12-13.

69 Malik, The Meaning of Race, s. 250.

70 Fred Halliday, Rethinking International Relations, Londra, Macmillan Press, 1994, s. 38.

71 Joseph, The Social in the Global, s. 112.

72 McNally, “Dil, Tarih ve Sinif Mücadelesi”, s. 48.

73 Morton Wenger, "Idealism Redux: The Class-Historical Truth of Postmodernism", Association for Critical Sociology, Cilt 20, No 1, 1994, s. 54.

74 Oyvind Osterud, “Antinomies of Postmodernism in International Studies”, Journal of Peace Research, Cilt 33. No.4, 1996, s. 387. 
görüntüsünü sunmaktadır. ${ }^{75}$ Mouzelis'e göre, postyapısalcı teoriler, derinlikten yoksun oluşunu, anlam-belirsizliğini yücelten kelime oyunlarıyla ve yarı şiirsel bir dille gizleme eğilimindedir. ${ }^{76}$ Malik'e göre ise "belirsizlik üzerindeki vurgu, toplumsal gerçekliği bütüncül bir şekilde kavrayamayacağımız inancından kaynaklanmaktadır".7 $\mathrm{Bu}$ açıdan post-modern teorileştirme "bizi, teorik bir inşanın, ne kadar tuhaf veya ham da olsa, bir başkası kadar doğru veya yanlış olduğuna ikna etmeye çalışan bir göreceliğin damgasını taşır." ${ }^{78}$

Postyapısalcı yaklaşımların en önemli kusurları sosyal hiyerarşilerle ilgilenmemeleridir. Diğer bir deyişle, postyapısalcıların sosyal olanı ne hiyerarşik anlamda ne de yapı-yapan, mikromakro anlamında kavranabilen bir söylemler seti olarak kavramsallaştırması, onların farklılaşmamış (undifferentiated) 'düz' bir ontolojiye sahip olduklarını göstermektedir. ${ }^{79}$ Örneğin Ashley’e göre, uluslararası politikanın ontolojisi "derin bir yapı” arkasında gizlenmiş değildir. Uluslararası politikanın ontolojisi, Realist güç politikasının pratiklerinde, tekniklerinde ve ritüellerinde - yani 'yüzeyin' tam ortasında - yer almaktadır. ${ }^{80} \mathrm{Bu}$ nedenle, Ashley'e göre, yapı yerine, pratiğe ve derinlik yerine yüzeye öncelik verilmelidir. ${ }^{81} \mathrm{Bu}$ çerçevede yapısökümü (deconstruction) yöntemi verili olarak alınan olguların, kavramların ve süreçlerin nasıl farklı, çelişkili ve rakip söylemlerin ürünü olarak ortaya çıktığını aktarmakla sınırlıdır. Diğer bir deyişle, yapısökümü yönteminin amacı, verili bir bütün olarak görünen olguların aslında parçalı ve değişken bir doğaya sahip olduklarını göstermektir. Ancak bu yaklaşım, görünüşlerin altında duran gerçek yapıların veya nedenlerin ortaya çıkarılması şeklinde anlaşılmamalıdır. Postyapısalcı bir yaklaşım olguların kökenlerine inmeyi amaç edinmez. Postyapısalcıların görüntü ve hakikat arasında bir ayrımın bulunmadığını düşünmeleri, onların analizlerinde sadece farklı söylemleri ifşa etmekle sınırlı kalmalarına yol açmaktadır. George ve Campbell gibi Uİdeki postyapısalcılar, farklılaşmadan (differentiation) ziyade farklılıklardan (differences) bahsetme eğilimindedir. ${ }^{82}$ Onlar analizlerinin çıkış noktası olarak sosyal yapıları değil, kimliğin karmaşıklığını vurgular. Ancak farklılaşmadan bahsedildiğinde bile, onun söylemlerin bir ürünü olduğu ima edilmektedir. ${ }^{83} \mathrm{Bu}$ bağlamda, postyapısalcı yazarlar söylem dışı bir gerçeklik ve hakikat ile ilgili iddialarının farklılıkların baskılanması ile ilgili bağlantısına dikkat çeker. ${ }^{84} \mathrm{Bu}$ tutum özellikle postyapısalcıların dış politika analizlerinde öne çıkmaktadır.

Örneğin, Doty gerek Neo-realistlerin, ${ }^{85}$ gerek Neo-Marksistlerin, güç dağılımından veya kapitalist üretim ilişkilerinden kaynaklanmış olsun, devletlerin birbirleriyle hiyerarşik bir biçimde

75 Pijl, A Survey of Global Political Economy, s. 263.

76 Mouzelis, Sociological Theory, s. 54-55.

77 Malik, The Meaning of Race, s. 253.

78 Mouzelis, Sociological Theory, s. 54-55.

79 Ibid.

80 Richard Ashley, “The Geopolitics of Geopolitical Space: Toward a Critical Social Theory of International Politics", Alternatives: Global, Local, Political, Cilt 12, No 4, 1987, s. 406.

81 Richard Ashley "Untying the Sovereign State: A Double Reading of the Anarchy Problematique”, Millennium, Cilt 17, No 2, 1988, s. 243.

82 Jim George ve David Campbell, "Patterns of Dissent and the Celebration of Difference”, International Studies Quarterly, Cilt 34, No 3, s. 269-293.

83 Bkz. Bahar Rumelili, “Constructing identity and relating to difference: understanding the EU's mode of differentiation”, Review of International Studies, Cilt 30, No 1, 2004, s. 27-47.

84 Maja Zehfuss, Constructivism in International Relations, Cambridge, Cambridge University Press, 2004.

85 Doty’nin bu argümanının, Neo-realizm ile benzer bir ontolojiyi paylaşan ve sistemik bağımlılığı söylemden bağımsız olarak kavrayan Neo-liberalizm için de geçerli olduğunu belirtmek gerekir. Bkz. Yücel Bozdağlığlu ve Çınar Özen, “Liberalizmden Neoliberalizme Güç Olgusu ve Sistemik Bağımlılı", Uluslararası İlişkiler, Cilt 1, No 4, 2004, s. 59-79. 
konumlanmış olduklarını varsaydıklarını belirtmektedir. ${ }^{86}$ Oysa Doty’e göre hiyerarşinin kendisi bir sosyal inşadır ve onun söylemsel pratikler içinde nasıl inşa edildiğini gösterdiğimizde, hiyerarşik yapının aslında metinlerarası bir inşa olduğu ortaya çıkmaktadır. ${ }^{87}$ Bununla birlikte, Doty'e göre bu ifşanın “derin yapı” yı ortaya çıkardığını söyleyemeyiz, çünkü “derin yapı”nın kendisi, söylemsel bir pratiktir. Bu 'yapıların' önemi ve gücü, onların "yorumlayıcı imkânları ifade etme, anlam yaratma ve böylece belirli bir meseleyi doğallaştırma yeteneklerinde bulunur." ${ }^{88} \mathrm{Bu}$ açıdan baktığımızda, hiyerarşi konumsal veya ilişkisel bir durum olmaktan çıkarak, tümüyle söylemsel bir inşaya indirgenmiş olmaktadır. Bu şekilde bir ilişki biçimi olarak hiyerarşinin ve farklılaşmanın (söylem dışı) nesnel boyutu örtülmüş olmaktadır. Hâlbuki farklılaşma "sosyal gruplar içinde ve arasındaki malların ve hizmetlerin eşit olmayan şekilde düzenlenmesi”ne işaret ettiği ölçüde, farklılaşmış sosyal konumlar açısından tanımlanan uluslararası sistemin yapısının nesnel bir özelliğidir. ${ }^{89}$

Postyapısalcıların gerçekliğin farklılaşmış ve katmanlı boyutunu ihmal etmesi ve ayrımlarla sınırların kaldırılması stratejisi, "karmaşık sosyal olguların indirgemeci bir biçimde işaretler, metinler ve 'arzular' açısından açıklandığı” ${ }^{\prime 0}$ bir sosyal bilim anlayışını doğurmuştur. Mouzelis, söz konusu bu kaba açıklamaların sosyal olguların güdüler, ırk, iklim ve coğrafya açısından açıklanmaya çalışıldığı Durkheim-öncesi açıklama girişimlerine bir geri dönüş olduğunu belirtmektedir. Ona göre "tek fark, günümüzdeki post-modernistlerin indirgemeci açılamalarını biyolojiden ve coğrafyadan ziyade, psikanalizden ve dilbilimden türetmeleridir". ${ }^{91}$

Başta bireysel öznelerin, söylemlerin bir bileşkesi olduğunu göstermeye çalışan Foucault'nun çalışmaları, "dilsel belirlenimcilik”"ten bireylerin güç ilişkileri tarafından oluşturulduğu düşüncesine kaymakla $^{92}$ birlikte farklılaşma ve yapısal eşitsizlikler ile ilgilenmez. Foucault’un güç kanalları olarak gördügü söylemsel pratikler anlayışı, "dilsel bir uzlaşı" veya "söylemin bir sonucu” olarak keyfi hakikat fikrinden uzaklaşıp iktidarın veya güç ilişkilerinin bir ürünü olarak hakikat fikrine yanaşmıştır. ElderVass'a göre, Foucault'nun sosyal teoriye en kalıcı katkılarından bir tanesi, bilgi iddialarının farkında olunmayan sosyal etkilere bağımlılı̆̆ını ortaya çıkararak verili bilgi varsayımlarının güvenirliliğini sarsmasıdır. ${ }^{93}$ Foucault’a göre modern iktidar, mevcut kapasitelerin kısıtlanması ve bastırılması yoluyla değil; yeni kimliklerin, bilgilerin ve pratiklerin yaratılmasıyla işler. ${ }^{94} \mathrm{Bu}$ anlamda, söylemsel pratikler kendi içlerinde iktidarı barındırdıkları gibi, iktidar ilişkileri de toplumun en kılcal damarlarına kadar uzanır. Öte yandan, Layder'in belirttiği gibi söylem ve pratik biçiminde bile olsa, iktidarın yayılması için "bir odak ve dayanak noktası olarak işleyen bazı yapısal ve kurumsal temelleri gerektirir." ${ }^{95}$ İktidar her yerde olsa bile, onun bütün topluma eşit olarak yayıldığı sonucunu çıkartamayız. Bu açıdan postyapısalcıların parçalanmış ve farklılaşmamış 'sosyal' ontolojisi, iktidar ilişkilerinin yapısal eşitsizlikleri ve diğer hiyerarşik iktidar biçimlerini kavrama konusunda yetersiz kaldığını söyleyebiliriz.

86 Roxanne Doty, "Foreign Policy as Social Construction: A Post-Positivist Analysis of U.S. Counterinsurgency", International Studies Quarterly, Cilt 37, No 3, 1993, s. 304.

87 Doty, “Foreign Policy as Social Construction”, s. 314.

88 Ibid., s. 314.

89 Jack Donnelly, “Differentiation: Type and Dimension Approaches”, Mathias Albert et al., (der.), Bringing Sociology to International Relations, Cambridge, Cambridge University Press, 2013, s. 91.

90 Mouzelis, Sociological Theory, s. 53-54.

91 Ibid., s. 54.

92 Sarup, An Introductory Guide to Post-structuralism, s. 73.

93 Elder-Vass, The Reality of Social Construction, s. 207.

94 Layder, Understanding Social Theory, s. 132.

95 Ibid. 


\section{Söylemsel Ontolojiye (Eleştirel) Gerçekçi Alternatif: Katmanlı Sosyal Ontoloji}

Postyapısalcılar için, söylem dışında bir sosyal gerçeklikten bahsedemeyiz, ${ }^{96}$ çünkü 'teori' (yorumlarımız) ve 'ampirik gerçeklik' arasında herhangi bir boşluk veya düalizm (görünüş-gerçek, mikro-makro gibi) bulunmamaktadır. ${ }^{97} \mathrm{Bu}$ nedenle, bilginin ontolojik düzlemi ile epistemolojik düzlemi arasında hiçbir ayrım yoktur. Bilgi ve gerçeklik, bir ve aynı şey olarak varsayılır veya bilgi-ötesi gerçekliğin (söylem yoluyla sağlanan bilginin dışında olan gerçeğin) anlamsız olduğu değerlendirilir. ${ }^{98}$ $\mathrm{Bu}$ epistemolojik kaygılar nedeniyle, postyapısalcılıkta gerçek ve sosyal gerçeklik, çok sayıda rakip söylemin bir sonucu olmaktadır. Richard Devetak'ın ifadesiyle perspektiflerimiz veya anlatılarımız "gerçek dünya"nın fabrikasıdır. ${ }^{99} \mathrm{Bu}$ açıdan, anlatılar sadece olguların anlaşılması için merkezi bir öneme haiz değildir, onlar aynı zamanda olguların ve gerçekliğin kurucusudur.

Ampiristler ve postyapısalcılar farklılıklarına rağmen, teori ile gerçeklik arasındaki ilişki konusunda epistemolojik bir kaygı paylaşır. Ampiristlergözlemlenemeyen varlıklarıbilebileceğimizden şüphe ederken, postyapısalcılar gerçekliğin kendisini bilebileceğimizden şüphe eder. ${ }^{100}$ Pozitivist anlayışa göre teori, sosyal gerçekliğin belirli alanlarında meydana gelen olgularda ampirik düzenlilikler belirlemek için kullanılan bir araç veya önermeler dizisi olarak kabul edilir. Postyapısalcı anlayışa göre ise teori, sosyal gerçekliğin bir temsili veya onu açıklamak için kullandığımız bir araç değil, sosyal gerçekliği bizzat kuran bir söylem, anlatı veya sosyal pratik şeklinde anlaşılmaktadır. ${ }^{101}$ Douglas Porpora, postyapısalcılığın, pozitivist akıl yürütmeyi ters yönde ilerlettiğini belirtir. Buna göre nelerin var olduğunu belirlemenin nesnel bir yolu olmadığı düşüncesi, nesnel bir şekilde var olan hiçbir şeyin var olmadığı veya insan kavramsallaştırmasının dışında bir gerçekliğin olmadığı sonucuna ulaşır. İnsan kavramsallaştırmaları kültürden kültüre değiştiği için de herkesin kendi hakikatini kurduğu düşünülür. ${ }^{102} \mathrm{Bu}$ açıdan epistemolojik nesnellik yoksa, ontolojik nesnellikten de bahsedilemez. $\mathrm{Bu}$ nedenle, söylem, metin veya kültür dışında olan nesnel sosyal yapılar olmadığı düşünülür. Özetle postyapısalcılar için gerçekliğe sadece 'bilgi' olarak örtbas edilen inançlarımız aracılığıyla erişebildiğimizden, nesnel bir gerçeklik mümkün değildir.

Sahip olduğumuz bilginin göreceli olduğu argümanı var olan tüm bilgiyi kapsayacak şekilde genişletilirse, ontoloji mümkün olmaktan çıkmakta veya epistemolojik önceliklerimize göre budanmış ve çarpıtılmış bir biçim almaktadır. Gerçekliği sadece teorilerimiz aracılığıyla bilebilirsek bile, hakikat teorilerimize indirgenemez. Teori ve hakikat eşit olsaydı, o zaman teoriye gerek kalmazdı. $\mathrm{Bu}$ argüman, sosyal bilim felsefesinde en açık ve sistematik biçimde eleştirel gerçekçilik tarafından ortaya konulmuştur.

96 Richard Ashley, "Living on Border Lines: Man, Poststructuralism, and War”, James Der Derian ve Michael J. Shapiro (der.), International/ Intertextual Relations: Postmodern Readings of World Politics, Lexington, Lexington Books, 1989, s. 262.

97 Mouzelis, Sociological Theory, s. 49-50.

98 David Campbell, Writing Security: United States Foreign Policy and the Politics of Identity, Minneapolis, University of Minnesota Press, 1998, s. 4-6; Jonathan Joseph, "Foucault and Reality", Capital \& Class, Cilt 28, No 1, 2004, s. 144.

99 Richard Devetak, "Theories, Practices and Postmodernism in International Relations 1", Cambridge Review of International Affairs, Cilt 12, No 2, 1999, s. 67.

100 Alexander Wendt, Social Theory of International Politics, New York, Cambridge University Press, 1999, s. 91.

101 Campbell, Writing Security, s. 19.

102 Douglas Porpora, Reconstructing Sociology: The Critical Realist Approach, New York, Cambridge University Press, 2015, s. 17-18. 
Eleştirel gerçekçilik sosyal bilim felsefesinde ve sosyal teoride hüküm sürmüş çeşitli pozitivist ve yorumsamacı felsefi yaklaşımlara bir tepki olarak gelişmiştir. Eleştirel gerçekçilik temelde, dünyada var olanın veya hakikatin (ontolojinin), ne bildiğimize ya da neye inandığımıza (epistemolojiye) bağlı olduğu görüşüne yönelik bir itirazı temsil eder. Bu anlamda, eleştirel gerçekçilik en temelde gerçekliğin bizim teorilerimizden, düşüncelerimizden ve bilincimizden büyük ölçüde bağımsız olarak var olduğunu öne süren felsefi bir duruştur. Ancak bu 'bağımsızlık', Sayer' in vurguladığı gibi, sosyal gerçekliğe doğrudan ya da basit bir erişimi değil, sosyal gerçeklik ve teorilerimiz arasında daha zor bir ilişkiyi ima etmektedir. ${ }^{103}$ Bir yandan, dünyaya dair bilgimiz her zaman mevcut betimlemeler, yorumlayıcı çerçeveler ya da söylemlerin bilgisidir. Roy Bhaskar sosyal olarak üretilen ve bilim insanlarının malzemelerini oluşturan bilginin bu boyutunu, "bilginin geçişli (transitive) nesnesi" biçiminde tanımlamaktadır. ${ }^{104}$ Öte yandan, bizlere dünyanın yalnızca (kolektif) düşüncenin bir ürünü olmadığı ile ilgili gerçekçi kanıyı veren şey, bilgimizin yanılabilirliği ve şeyleri yanlış anlayabilmiş olmamız ile ilişkin deneyimimizdir. Hatalı olma ihtimaliyle ilgili tecrübemiz gösterir ki, dünyaya dair bilgimiz her zaman mevcut söylemler içinde ve bu söylemler aracılığıyla kavramsallaştırılmış olmasına rağmen, yine de dünyadan bir tür geri bildirim alırız. ${ }^{105}$ Sayer'in vurguladığı gibi, dünyanın doğasının gözlemcinin onun hakkındaki fikirlerinden bağımsız olduğu düşüncesi, "mevcut bilgimizin hem uygunluğunu hem de yanlışlanabilirliğini açıklar." ${ }^{106}$ $\mathrm{Bu}$ anlamda bilgimizin yöneldiği ve açıklamaya çalıştığı nesne, bizim teorilerimize indirgenemeyen "bilginin geçişsiz (intrasitive) nesnesine" veya ontolojik boyutuna işaret eder.

Collier' in isabetli bir şekilde ortaya koyduğu gibi, rakip bilimsel teoriler bilginin 'geçişli' nesnesi olarak farklı epistemolojik duruşlara sahip oldukları için birbirlerinden farklıdır; ancak onları rakip yapan şey, onlardan bağımsız olarak var olan, aynı 'geçişsiz' nesne ile ilgili bilgimizi derinleştirmeye çalışmalarıdır. ${ }^{107} \mathrm{Bu}$ anlamda teoriler, postyapısalcılık örneğinde olduğu gibi yorumladıkları gerçekliğin kendisi değil, bilimi gerçeklik ile dolaylı biçimde bağlamaya çalışan bilimin 'geçişli' nesneleridir. ${ }^{108}$ Teoriler hem dünyayı anlamak için bir yorumlama çerçevesi sunar hem de olguları üreten nedensel mekanizmaları ve yapıları kavramsallaştıran açıklayıcı bir çerçeve sunar. ${ }^{109}$ Tüm teoriler 'geçişsiz' veya nesnel bir boyut karşısında yanlışlanabilir. Bununla beraber, tüm teoriler veya bilgi eşit derecede yanlışlanabilir değildir. Sosyal olarak üretilen bilgi sürekli 'geçişsiz' nesne ile bir etkileşim içerisinde (veya nesnel bir ontoloji karşısında) üretildiği için bilginin geçerliliği hakkında veya teorilerin açıklayıcı gücü konusunda, rasyonel muhakeme aracılığıyla bir tercihte bulunmak mümkündür. Rasyonel muhakeme, epistemolojik göreceliğe rağmen, teorilerin sundukları açıklamaların uygunluğuna dayanarak, rekabet eden teoriler arasında bir seçimin yapılabileceğini göstermektedir. ${ }^{110} \mathrm{Bu}$ anlamda, epistemolojik gerçekçilik, olgular hakkındaki bilginin eksik ve yanlışlanabilir olduğunu ve teoriler aracılığıyla elde edildiğini, buna rağmen gerçekliğin doğrudan olmazsa da bilinebilir ve kavranabilir olduğunu varsaymaktadır. ${ }^{11}$

103 Andrew Sayer, "Foreword: Why Critical Realism?", Steve Fleetwood ve Stephen Ackroyd (der.), Critical Realist Applications in Organisation and Management Studies, Londra, Routledge, 2004, s. 6.

104 Roy Bhaskar, A Realist Theory of Science, New York, Routledge, 2008, s. 5-6.

105 Sayer, “Foreword: Why Critical Realism?”, s. 6.

106 Andrew Sayer, Sosyal Bilimde Yöntem: Realist Bir Yaklaşım, çev. Sabri Gürses, İstanbul, Küre Yayınları, 2017, s. 11.

107 Andrew Collier, Critical Realism: An Introduction to Roy Bhaskar's Philosophy, Londra, Verso, 1994, s. 51.

108 Berth Danermark et al., Toplumu Açılamak: Sosyal Bilimlerde Eleştirel Realizm, çev. Ümit Tatlıcan, Ankara, Phoenix, 2018, s. 48-49.

109 Ibid., s. 189.

110 Wight, Agents, Structures and International Relations, s. 26.

111 Bunge, Chasing Reality, s. 29. 
$\mathrm{Bu}$ şekilde eleştirel gerçekçiliğe göre bilimsel çalışma, "deneyimlediğimiz şeyleri, fiilen olan şeyleri ve dünyadaki olayları üreten temel mekanizmalar arasındaki ilişkileri ve ilişkisizlikleri araştıran ve ortaya koyan” bir faaliyettir. ${ }^{112} \mathrm{Bu}$ açıdan eleştirel gerçekçilik, sosyal araştırmanın meşru nesnesi olarak, sadece görünümleri veya dünyanın insanlara nasıl göründügünü ele alan fenomenalizm karşıtlığı nedeniyle hem pozitivizmden hem de yorumsamacılıktan ayrılmaktadır. Bu şekilde eleştirel gerçekçilik, öznelerarası anlamlar veya söylemsel pratikler dışında nesnel bir gerçeklik bulunduğu iddiasıyla yorumsamacılıktan ayrılırken; gerçekliği doğrudan gözlemlenen ampirik düzenliliklere indirgemesi nedeniyle gerçekliğin katmanlaşmış doğasını göz ardı eden 'ampirik realizmden' (pozitivizmden) de ayrılmaktadır. ${ }^{113}$ Eleştirel gerçekçilik bu kapsamda katmanlı bir gerçeklik anlayışı ortaya koyar. Buna göre gerçeklik, ampirik, fiili ve reel olarak üç alandan oluşur. Fiili alan deneyimlerden bağımsız olarak gerçekleşen olayları kapsarken; ampirik alan olayların gözlemlenen düzenlilikleri ve örüntüleri ile ilgilidir. Reel alan ise bilimin keşfetmeye çalıştığı olayları üreten veya gözlemlenen biçimi almalarını sağlayan, fiilen gözlemlenmeyen gerçek doğurgan mekanizmalar, yapılar, güçler ve eğilimlerin katmanıdır. ${ }^{114}$

Bhaskar’a göre bu üç alanın kendine özgü oluşumsal özelliklerini ve gerçekliklerini göz ardı ettiğimizde, onları birbirine indirgeme hatasına düşebiliriz. Bu kapsamda eleştirel gerçekçiliğin, konumuz açısından, sosyal teoriye en dikkate değer katkısının sosyal yapıların ampirik veya etkileşim düzeyinde değil, reel düzeyde kavranması için sunduğu çerçeve olduğu iddia edilebilir. Eleştirel gerçekçiliğe göre sosyal hakikat, basitçe söylemsel pratiklerin bir ürünü değil; sosyal pratikler, yapılar ve doğurgan mekanizmalar arasındaki karmaşık etkileşimden oluşmaktadır. ${ }^{115}$ Bhaskar’a göre sosyal yapılar, hem aktörlerin etkinlikleri için kaynakları ve araçları sağlayan zorunlu koşullardır hem de eylemlerinin sonucudur. Bu nedenle sosyal yapılar aktörlerin etkinliklerine ve kavramsallaştırmalarına indirgenmeyen kendine özgü oluşumsal özellikler taşıyan toplumsal ilişkiler biçiminde anlaşılmalıdır. ${ }^{116}$ Sosyal yapılar, insan etkinliklerine bağımlı olsalar da geçmişte girişilen eylemlerin ürünü olduklarından, eylemi önceler ve mevcut etkileşime indirgenemez. Bu nedenle, aktörler yapıları yaratmaktan ziyade, rutin eylemleriyle ya bilinçsizce onları yeniden üretirler ya da bazen aktif olarak onları dönüştürürler. ${ }^{17} \mathrm{Bu}$ anlamda sosyal yapıların, sahip olduğumuz anlayışlardan bağımsız, nesnel bir varoluşa sahip olduklarını öne sürebiliriz. Bu açıdan sosyal yapılar, sosyal hakikatin derin katmanını oluşturur.

\section{Söylemsel Pratikler ve Bir Bağlam Olarak Sosyal İlişkiler}

Postyapısalcılığın (büyük anlatı olarak gördüğ̈̈) herhangi bir teoriyi reddetmesi, söylem dışı bilginin olanaklılığını reddetmesine neden olan realizm karşıtı tutumundan kaynaklanmaktadır. Bu tutum aynı zamanda söylemin sosyal bağlamdan bağımsız bir alan olduğu fikrine yol açar. ${ }^{118}$ Eğer sosyal hakikat

112 Danermark et al., Toplumu Açıklamak, s. 46.

113 Patrick Baert, Sosyal Bilimler Felsefesi: Pragmatizme Doğru, çev. Ümit Tatlıcan, İstanbul, Küre, 2018, s. 131.

114 Faruk Yalvaç, "Eleştirel Gerçekçilik: Uluslararası İlişkiler Kuramında Post-Pozitivizm Sonrası Aşama”, Uluslararası İlişkiler, Cilt 6, No 24, 2010, s. 10.

115 Jonathan Joseph, "Hegemony and the Structure-Agency Problem in International Relations: A Scientific Realist Contribution", Review of International Studies, Cilt 34 No 1, 2008, s. 110.

116 Roy Bhaskar, The Possibility of Naturalism, New York, Routledge, 1998, s. 40-42.

117 Ibid., s. 37-38.

118 Callinicos, “Postmodernism, Post-structuralism, Post-Marxism?”, s. 96 
tümüyle söylem aracılığıyla inşa edilmişse, o zaman aktörlerin anlamları ve yorumları kıyaslamak veya rakip iddialar arasından bir seçim yapıp belirli bir yargıya varmak imkânsız hale gelmektedir. Kısaca 'epistemolojik görecelik' bir 'yargısal göreceliğe' yol açarak, tüm yorumların eşit derecece geçerli olduğu bir anlayış doğurmaktadır. Sayer'in isabetli ifadesiyle, "eğer hakkında yanılabileceğimiz herhangi bir nesnel durum olmasaydı, o zaman istediğimiz fikirleri uydurabilirdik ve onlar yanlışlanamaz olurdu”. ${ }^{119}$ Böylece nesnel bilgiden, doğruluktan ve hakikatten bahsedilemeyeceği bir durum ortaya çıkmaktadır. ${ }^{120}$ Postyapısalcıların savladığı gibi "hakikat yoksa, doğru ve yanlış görüşleri birbirinden ayırmanın hiçbir nesnel aracı yoksa, o zaman kimin perspektifinin geçerli olacağına karar verecek tek şey olarak iktidar kalmış demektir”. ${ }^{121}$

Eleştirel gerçekçiliğin katmanlı ontolojisini esas aldığımızda, postyapısalcıların bilgi biçimlerini bilgi nesneleriyle birleştirdikleri veya birbiriyle karıştırdıkları ortaya çıkar. Bu durumda Bhaskar'ın sözünü ettiği ontolojiyi epistemolojiye indirgeme hatası, yani "epistemolojik yanılgı" kendini en açık biçimde göstermektedir. ${ }^{122}$ Oysa Bunge’nin belirttiği gibi, bir olgunun gerçek anlamı mutlaka görünür olmadığı için yorumlanmayı veya kavramsallaştırmayı gerektirdiği düşüncesi (epistemolojik İnşacılık) doğru bir yaklaşım sunarken, olgunun gerçek anlamının yorumlara indirgenebileceğini savunan "ontolojik İnşacılık" (ontological constructivism) hatalı bir yaklaşıma işaret eder. ${ }^{123}$ Postyapısalcılığın bilginin toplumsal bir ürün olduğu vurgusu doğru olmakla birlikte, "bilginin önceden bulunan bir materyalin söylem dışı bir referans ile sürekli bir şekilde etkileşime girmesi yoluyla dinamik bir biçimde üretilen bir sosyal ürün” ${ }^{124}$ olduğu hususu, postyapısalcılar tarafından dikkate alınmamaktadır. Andrew Sayer'in belirttiği gibi:

"Söylemler, maddi koşulların salt yansımaları değildir; ne de maddi şartlar sadece söylemlerin somutlaştırmalarından ibarettir. Söylemler, pratikler aracılı̆̆ıyla - özellikle, daha önceki sosyal inşalar ya da 'yapılanma' çevrimlerinden miras kalan ve kendine özgü özelliklere ya da eğilimlere sahip olan maddi ve sosyo-dilsel bağlamlar aracilığıyla - şekillenir."125

Porpora, katmanlı sosyal ontolojisi çerçevesinde sosyal yapıları söylemsel bir gerçeklikten ziyade nesnel bir gerçeklik biçiminde 'toplumsal ilişkiler' olarak tanımlamaktadır. Toplumsal ilişkiler olarak kavramsallaştırılan sosyal "yapının bireyler üzerindeki nedensel etkileri, ilişki ağı tarafından her bir pozisyona yerleştirilen belirli yapısal çıkarlar, kaynaklar, güçler, kısıtlamalar ve çıkmazlarda açığa çıkar." ${ }^{126} \mathrm{Bu}$ açıdan toplumsal ilişkiler, "insanların içinde hareket etmek zorunda kaldıkları ve onları belirli şekillerde hareket etmek için motive eden maddi koşulları oluşturur." ${ }^{27}$ Ancak toplumsal ilişkiler kaba bir maddecilik anlamına gelmez. Örneğin, üretim ekonomik bir ilişki olduğu kadar; belirli sosyal, kültürel ve siyasi süreçleri de ima eder.Joseph’in dikkatimizi çektiği üzere, kapitalizm özel

119 Sayer, Sosyal Bilimde Yöntem, s. 12.

120 Steve Fleetwood, "Bhaskar and critical realism", Paul Adler, (der.), Oxford Handbook of Sociology, Social Theory and Organisation Studies: Contemporary Currents, Oxford, Oxford University Press, 2014, s. 186.

121 Rosenau, Post-Modernism and the Social Sciences, s. 147.

122 Joseph, "Foucault and Reality", s. 144.

123 Mario Bunge, "Realism and Antirealism in Social Science", Theory and Decision, Cilt 35, No 3, 1993, s. 215.

124Jonathan Joseph, "Terrorism as a Social Relation within Capitalism: Theoretical and Emancipatory Implications", Critical Studies on Terrorism, Cilt 4, No 1, 2011, s. 26.

125 Sayer, “Foreword: Why Critical Realism?", s. 7.

126 Douglas Porpora, “Four Concepts of Social Structure”, Margaret Archer et al., (der.), Critical Realism: Essential Readings, Londra, Routledge, 1998, s. 344.

127 Ibid. 
mülkiyet ilişkileri olmadan düşünülemez. Mülkiyet ilişkileri ise, siyasal egemenlik tarafından güvence altına alınan yasal bir çerçeve ve bu ilişkilerin meşruiyetine duyulan bir inançla kurulmaktadır. ${ }^{128}$ Öte yandan, kapitalist üretim biçimini meydana getiren bu ilişkiler, gözlemlenmezse veya bir söylemle dile getirilmezse de nedensel etkilerini gösterirler. ${ }^{129}$

$\mathrm{Bu}$ anlayışa göre, sosyal yapilar yönettikleri aktörlerin etkinliklerinden bağımsız değiller ve ancak görece anlamda istikrarlı olabilirler. Öte yandan, maksatlı eylemin her zaman niyetlenilmiş sonuçlar doğurmaması ve aktörlerin kendi eylemlerinin sonuçları hakkında farkında olmamaları gibi sebeplerle sosyal yapılar nesnel toplumsal ilişkilere işaret ederler. Toplumda bulunan eşitsizlik, bağımlılık, iş bölümü ve kaynak dağılımı gibi çeşitli sosyal ilişkilerin aktörler üzerinde etki doğurabilmeleri veya mevcudiyet kazanabilmek için mutlaka bir söylem tarafindan dile getirilmeleri gerekmemektedir. Sosyal yapıların, aktörlerin onlar hakkında sahip oldukları düşüncelere veya aktörlerin sosyal pratiklerine indirgenemeyen (zamansal öncelik ve süreklilik; eylemi eşitsiz ilişkiler içerisinde konumlandırma; kaynaklara farklılaşmış erişim sağlama vb.) özellikler taşıdığını kabul ettiğimizde, söylemsel pratiklerin sosyal yapılar tarafından belirlendiği sonucu ortaya çıkmaz. Yapılar sonuçları belirlemekten ziyade bazı söylemsel pratikleri diğer bazılarına göre daha mümkün kılarak veya belirli eylemleri kısıtlayarak etkilerini gösterir. Bu çerçevede yapılara içkin ilişkisel ve hiyerarşik konumlar, deneyimlendiğinden bağımsız olarak var olurlar ve nedensel güçler taşırlar. Örneğin hegemon bir devletin uluslararası sistemdeki konumu kendi başına nedensel bir koşul oluşturur. Joseph ve Kurki'nin belirttiği gibi, pratikler sosyal açıdan anlamlı eylemler oldukları halde, onların anlamlılığı basitçe aktörlerin kavrayışlarına bağlı olmayıp sıkça bilinç düzeyinden kaçan derindeki sosyal yapıların yeniden üretimi ve dönüşümü ile ilişkisine dayanmaktadır. ${ }^{130}$ Örneğin, neoliberal küreselleşme ile ilgili 1980 'lerden itibaren öne çıkan söylemsel pratiklerin, 1970'lerden itibaren Batı toplumlarındaki devlet-toplum ve devlet-piyasa ilişkilerinde meydana gelen bir dizi yapısal değişimleri dikkate almaksızın, neden ortaya çıktıkları ve etkili oldukları anlaşılamaz. Aynı şekilde, sosyalist gelişme modelinin çöküşünden sonra eski Doğu Bloku ülkelerinde sosyal devlet söylemi yerine neoliberalizmin hâkim olması, (sosyal-demokrat uzlaşının bozulması gibi) 1980'lerden itibaren dönüşüme uğrayan toplumsal ilişkiler bağlamında anlam kazanmaktadır. Postyapısalcıların yaptığı gibi, sosyal yapıların nesnel ve gerçek doğasını reddettiğimizde, söylemler arasındaki hiyerarşik konumlamalar ancak diğer söylemlere başvurarak açıklanmak zorunda kalacağından, söylemsel bir kısır döngü ortaya çıkar. Buna göre iliştirilmiş liberalizmden (embedded liberalism) neoliberalizme geçişin, basitçe yeni bir neoliberal söylemin icat edilmesiyle ve pratiklere yansıtılmasıyla gerçekleştiği düşünülebilir. Oysa ABD hegemonyasının ve küresel kapitalizmin bir söylemsel pratikten ziyade, pratikleri yönlendiren bir sosyal yapı olarak görülmesi gerekir. ${ }^{131} \mathrm{Bu}$ açıdan söylemsel pratikler, yapısal olarak üretilen seçenekler yelpazesi bağlamında inşa edilir. Buna göre belirli anlatıların hâkim söylem haline gelmeleri belirli yapılar ve güç ilişkileri içinde konumlanan aktörlerin pratikleri ve stratejileri bağlamında gerçekleşmektedir.

128 Jonathan Joseph, "Philosophy in International Relations: A Scientific Realist Approach”, Millenium, Cilt 35 No 2, 2007, s. 351.

129 Yalvaç, "Eleştirel Gerçekçilik", s. 24.

130 Jonathan Joseph ve Milja Kurki, “The Limits of Practice: Why Realism can Complement IR's Practice Turn”, International Theory, Cilt 10, No 1, 2018, s. 90.

131 Ibid., s. 90. 


\section{Sonuç}

Ontolojiyi nasıl anladığımıza ve kavramsallaştırdığımıza bağlı olarak bilgi, pratikler, yapılar ve gerçeklik arasındaki ilişkiyi de belirleme eğiliminde oluruz. Bu makale, post-pozitivist çevrelerde giderek genel bir kabul görme eğiliminde olan postyapısalcılığın göreceli ontoloji kavrayışının temelini oluşturan söylemsel pratiklerin sosyal gerçekliği kurduğu fikrinin eleştirisini ortaya koymaya çalışmıştır. Postyapısalcıların modern sosyal teoriye yönelik itirazları, söylem dışı gerçekliği reddeden tutumları karşısında anlaşılabilir. Ekstrem bir sosyal İnşacılık örneği temsil eden postyapısalcılığın esas niteliği ve kusurları, bilgi ve gerçeklik arasında varsaydığı hatalı ilişki çerçevesinde ortaya çıkmaktadır. Postyapısalcılık gerçeklik (ontoloji) ve gerçeklik hakkındaki teorilerimiz (epistemoloji) arasındaki ayrımı reddederek sosyal gerçekliği dile indirgenmesini ve dolayısıyla sosyal yapıları dilsel yapılara bir tutmayı beraberinde getirmiştir. Bu eğilim, sosyal gerçekliğin söylemler veya dilsel uzlaşılar tarafından tüketildiği görüşünü öne çıkartarak, yapısal analizlerin yapısökümü lehine terk edilmesiyle sonuçlanmıştır. Makale, söylemsel ontoloji çerçevesinde öznenin yanında, yapının da kendine özgü özelliklerini yitirdiğini ve söylem içinde kaybolduğunu ortaya koymuştur.

Eleştirel gerçekçilik bilimsel bilgiyi toplumsal bir ürün olarak gördüğü için insan bilgisinin güç ilişkileri barındırdığı ve belli kurumsal ve söylemsel bağlamlar çerçevesinde geliştiğini kabul eder. Bununla birlikte bilginin güç ilişkilerine indirgenmesine karşı çıkar. Epistemolojik düzlemdeki bilgi-iktidar kavrayışı, ontolojik düzlemdeki söylem dışı alan bilgisiyle ilişkilendirilmediği takdirde yapısökümü seviyesinde kalmaya mahkûmdur. ${ }^{132}$ Eleştirel gerçekçilik söylemsel pratiklerin söylem dışı alandaki sosyal yapıların yeniden üretilmesi ve dönüştürülmesi ile ilişkisi çerçevesinde anlaşılması gerektiğini önerir.

Katmanlı bir sosyal ontoloji, sosyal yapıların sadece söylemsel pratiklerin bir yan etkisi olduğu veya onlar içinde bir anlam ve varoluş kazandığı görüşüne itiraz eder. Katmanlı bir sosyal ontolojiye göre, toplumsal ilişkiler olarak kavranan sosyal yapılar, gerçekte söylemsel pratiklerin üzerine inşa edildiği veya bu pratikleri şekillendiren derin sosyal bağlamı meydana getirmektedirler. Bu anlamda söylemsel pratikler sosyal yapılarla eşit veya onların yaratıcısı değildir. Söylemsel pratikler kendilerini önceleyen ve önceden varolan sosyal yapılar içindeki konumlarından hareketle anlamlar sistemlerinin yeniden üretilmesinde veya dönüştürülmesinde (öznelerarası etkileşim düzeyinde) önemli bir rol oynayan öğeler olarak anlaşılması gerekmektedir. Söylemsel pratikler ve inşalar söylem dışı bir referansla etkileşerek dinamik bir biçimde oluşurlar. Diğer bir deyişle, belli sosyal inşaları mümkün kılan şey altta yatan gerçekliği ifade eden toplumsal yapılardır. Buna göre söylemsel pratikler belli anlamları mümkün kılarken, söylemsel pratiklerin kendileri de toplumsal yapılar tarafından mümkün kılınmıştır. Eğer söylemsel pratikler sosyal hakikatin kurucusu başta olmak üzere sosyal yapılarla eşit olsaydı, o zaman her söylemin birbirine eşdeğer etkilerde bulunmasını beklememiz gerekirdi. Böyle bir durumda, tüm söylemler 'aynı' olacağı için, neden belirli söylemler hâkim olurken diğerlerinin etkisiz kaldığı sorusu, çoklu söylemlerin rastlantısallığına ve belirsizliğine dayanacağından doyurucu bir biçimde cevaplanmadan kalmış olurdu. Söylemler ancak sosyal yapılar içinde eşit olmayan veya hiyerarşik bir biçimde konumlanan aktörlerin pratikleri olarak kavrandıklarında neden belirli söylemlerin önem ve etki kazandığı ve diğerlerinin geri planda kaldığı anlaşılabilecektir. Sosyal yapılar söylemsel pratiklerin koşullarını oluştururlar. Bu kapsamda sosyal yapılar ile ilgili bilginin üretilmesi, onların söylemsel pratikler ve aktörler ile ilişkisini görünür kılarak sosyal yapıların ve güç ilişkilerin dönüştürülmesi yönünde önemli bir adım oluşturmaktadır.

132 Joseph, "Foucault and Reality", s. 163. 